\title{
Bone morphogenetic proteins in breast cancer: dual role in tumourigenesis?
}

\author{
Emma-Leena Alarmo and Anne Kallioniemi
}

Laboratory of Cancer Genetics, Institute of Medical Technology, University of Tampere and Tampere University Hospital, FIN-33014 Tampere, Finland

(Correspondence should be addressed to A Kallioniemi; Email: anne.kallioniemi@uta.fi)

\begin{abstract}
The human bone morphogenetic protein (BMP) family consists of over 20 growth factor proteins that are involved in bone formation and developmental processes. BMPs are extracellular signalling molecules that are able to regulate various cellular functions, proliferation, differentiation, apoptosis and migration. For the last 10 years, these powerful cytokines have increasingly been studied in several cancers, and aberrant expression patterns of BMPs have been reported. Functional studies have suggested that BMPs are involved in both cancer promotion and inhibition. The role these signalling molecules play in breast cancer is only starting to emerge: thus far, studies have been even contradictory. Different BMP ligands have been shown to decrease as well as increase cancer cell growth and migration. Furthermore, they are involved in bone metastases, which are a common feature in breast cancer. In this sense, BMPs resemble a closely related protein transforming growth factor $\beta$, which possesses a bidirectional role in cancer cell regulation. In this review, we focus on the current knowledge of BMP expression, functional roles and involvement in bone metastasis in breast cancer.
\end{abstract}

Endocrine-Related Cancer (2010) 17 R123-R139

\section{Introduction}

Bone morphogenetic proteins (BMPs) are extracellular signalling molecules that constitute the largest branch of the transforming growth factor $\beta$ (TGF $\beta$ ) superfamily (Kawabata et al. 1998, Chang et al. 2002). By regulating target gene transcription, these growth factors control various cellular processes, such as proliferation, differentiation, apoptosis and migration. BMPs were originally identified based on their ability to form bone at extraskeletal sites (Wozney et al. 1988, Reddi 1997, Wozney 2002); currently, they are well known to play critical roles in diverse developmental phases (Hogan 1996a, Zhao 2003). These kinds of powerful developmental pathways are frequently disrupted in cancer (Kelleher et al. 2006), and for the last decade, BMPs have been increasingly focused upon in cancer research.

Cancer is in essence a genetic disease that is caused by accumulation of genetic alterations in oncogenes and tumour suppressor genes. Studies of inheritable cancer predisposition syndromes indicate that components of the BMP signalling pathway could act as tumour suppressors. In Juvenile polyposis syndrome, germline mutations of the BMPRIA receptor are detected in $20-25 \%$ of cases, and mutations of the cytosolic signalling transducer SMAD4 are detected in 15-20\% of cases (Waite \& Eng 2003a). BMPRIA mutations are also associated with some cases of Cowden syndrome (Harradine \& Akhurst 2006). In addition, SMAD4 is mutated in half of all sporadic pancreatic cancers and in one-third of sporadic metastatic colon cancers (Massague et al. 2000). SMAD8, another cytosolic signalling transducer, was shown to be silenced by an epigenetic mechanism in one third of breast cancers (Cheng et al. 2004). Thus far, in breast cancer, either heritable or somatic genetic alterations have not been detected in the BMP ligands themselves. In somatic cancers, several in vitro and in vivo studies have examined BMPs in various cancer types originating from a plethora of different tissues such as breast, prostate, bone, skin, lung, pancreas, colon, intestine, brain and ovaries (Kleeff et al. 1999, Yoshikawa et al. 2004, Hsu et al. 2005, Kim \& Kim 2006, Langenfeld et al. 2006, Piccirillo et al. 2006, Bleuming et al. 2007, Deng et al. 2007, Theriault et al. 2007, Ye et al. 2007). 
There has been a gradual increase in the understanding of the role that BMPs play in cancer. However, the number of studies is still limited even within breast and prostate cancer, which are the most studied tumour types. Furthermore, results are often contradictory. The same ligand can act differently depending on the cancer type, and it is likely that multiple members in the BMP family should not be examined as simply equals. Even the same BMP ligand within the same cancer type seems to act differently depending on the study. The current consensus is that BMPs are involved in both promotion and inhibition of cancer progression. Such a phenomenon has been reported for the superfamily member TGF $\beta$, which inhibits epithelial cell proliferation through a wellcharacterised cytostatic programme; however, during cancer progression, this growth inhibition is often lost (Derynck et al. 2001, Siegel \& Massague 2003, Massague \& Gomis 2006). Moreover, TGF $\beta$ induces epithelial-mesenchymal transition (EMT), has proangiogenic and immunosuppressive effects, and is evidently also involved in the metastatic process. Whether similar bidirectional action applies for BMPs is still unknown.

The purpose of this review is to elucidate the current knowledge of BMPs in breast cancer pathogenesis.

\section{Bone morphogenetic proteins}

\section{Structure}

Members of the TGF $\beta$ superfamily (BMPs, TGF $\beta$ s, activins, inhibins, NODAL and anti-Mullerian hormone) share a similar structure and a signalling pathway (Schmierer \& Hill 2007). BMPs, some of which are called growth and differentiation factors (GDF), are dimeric molecules composed of two identical monomers linked with a disulfide bond (Kingsley 1994, Reddi 1998, Ducy \& Karsenty 2000, Sebald et al. 2004). The core monomer contains a common structure called a 'cysteine knot' with seven highly conserved cysteines (Griffith et al. 1996). Currently, there are 21 known members in the human BMP family (BMP2-BMP7, BMP8A/B, BMP10, BMP15, GDF1-3, GDF5-7, myostatin, GDF9-11 and GDF15; Schmierer \& Hill 2007). These growth factors can be further divided into subgroups according to their amino acid sequences (Kawabata et al. 1998, Newfeld et al. 1999, Botchkarev 2003, Ye et al. 2007).

BMPs are translated as a large pre-proprotein containing a signal peptide sequence, a pro-domain and a mature growth factor domain (Kingsley 1994, Sebald et al. 2004). Prodomains are required in the dimerisation process and are cleaved at the consensus site RXXR (Ducy \& Karsenty 2000). Mature dimeric BMP is secreted out of the cell, but the prodomain may remain attached non-covalently; thus, the prodomain is thought to regulate BMP activity and availability (Constam \& Robertson 1999, Gregory et al. 2005, Sopory et al. 2006). In contrast to the well-known regulation of TGF $\beta$ isoforms by their prodomains (Keski-Oja et al. 2004), functions of different BMP prodomains are not yet thoroughly studied. Homodimers seem to be the major form of BMPs, but they exist also as heterodimers that can be even more biologically active than homodimers (Aono et al. 1995, Israel et al. 1996, Zhu et al. 2006).

\section{Function}

BMPs are unique in their ability to initiate bone formation (Wozney \& Rosen 1998). They stimulate the differentiation of mesenchymal cells into chondroblasts and osteoblasts and the subsequent new bone construction during embryogenesis as well as during bone repair processes in adult tissues (Reddi 1997, Wozney \& Rosen 1998, Wozney 2002). BMP subfamily members differ greatly in their osteogenic activities, and not all ligands are osteoinductive by nature (Luu et al. 2007). BMP2 and BMP7 have been studied the most in clinical applications and are currently used as treatment options in orthopaedics (Luo et al. 2005). Perhaps even more important than osteoinduction is the role BMPs play in different developmental phases. They regulate the primal stages of embryogenesis, formation of left-right asymmetry, neural and skeletal patterning, limb formation, and organogenesis (Hogan 1996a, Zhao 2003). Certain BMPs are vital for development because it has been previously shown that Bmp2 and Bmp4 null mutant mice die during embryogenesis, and Bmp7 null mutant mice shortly after their birth (Hogan 1996b). Not much is known about the function of BMPs during breast development. Because BMP-specific receptors are expressed in the developing mammary gland, this suggests that there is also active BMP signalling (Wakefield et al. 2001). Thus far, only Bmp2 and Bmp4 have been proposed to regulate the development of mouse mammary glands (Phippard et al. 1996, Cho et al. 2006).

\section{Signalling pathway}

In addition to their common structure, BMPs and other members of the TGF $\beta$ family share a common signalling pathway. There are several excellent reviews that illustrate well the rough backbone of the 
TGF $\beta$ superfamily signalling pathway (Heldin et al. 1997, Kawabata et al. 1998, Shi \& Massague 2003, ten Dijke \& Hill 2004, Miyazono et al. 2005, Massague \& Gomis 2006, Schmierer \& Hill 2007). Briefly, the ligand binds to two separate transmembrane serinethreonine kinase receptors, type I and type II, forming a heterotetrameric complex. In the complex, type II receptor phosphorylates and activates the type I receptor that in turn is able to phosphorylate and activate cytosolic SMAD proteins. Receptor-regulated SMADs (R-SMADs) form complexes with common SMAD (Co-SMAD), and these active SMAD complexes regulate transcription of target genes in the nucleus. A schematic illustration of BMP signalling is presented in Fig. 1. Because there are numerous ligands in the superfamily and only limited number of receptors and SMADs, extensive signalling regulation is necessary to achieve a specific response (Feng \& Derynck 2005). The BMP-specific features of the signalling pathway and its regulation are discussed below.

BMP ligands can bind three different type I and three different type II receptors (Kawabata et al. 1998, ten Dijke et al. 2003, Nohe et al. 2004, Miyazono et al. 2005). Type I receptors include BMP receptor type IA (BMPR1A or ALK-3), BMP receptor type IB (BMPR1B or ALK-6) and activin A receptor type I

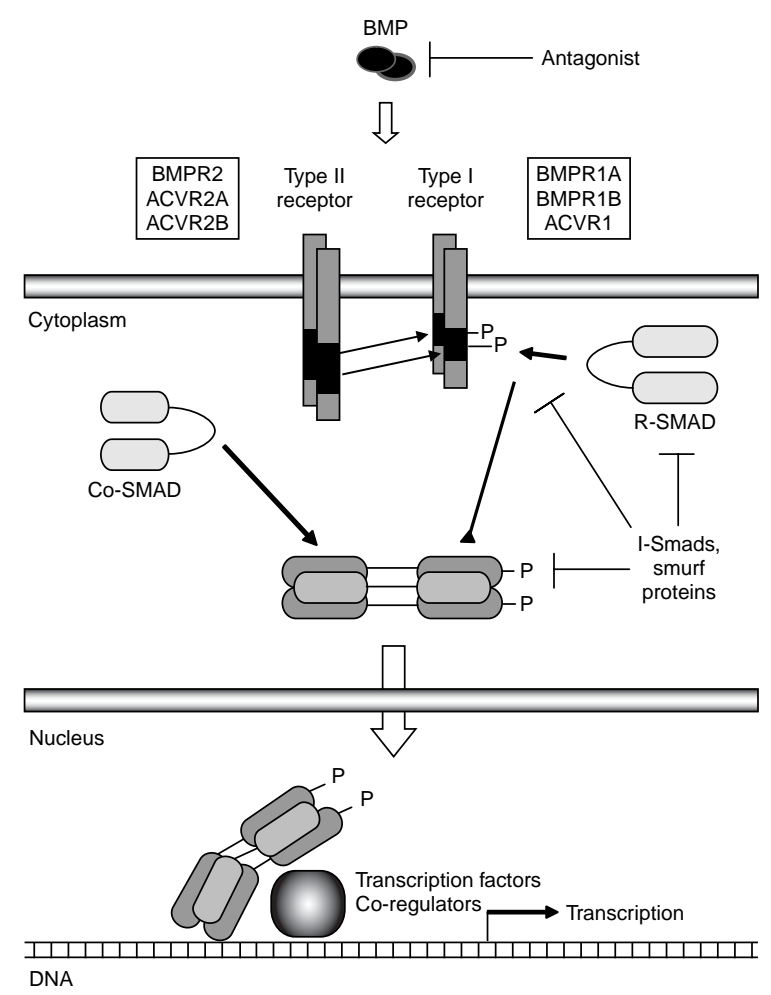

Figure 1 Schematic presentation of BMP signalling pathway.
(ACVR1 or ALK-2). Type II receptors include BMP receptor type II (BMPR2), activin A receptor type IIA (ACVR2A or ActR-II) and activin A receptor type IIB (ACVR2B or ActR-IIB). Both receptor types consist of an $\mathrm{N}$-terminal extracellular ligand-binding domain, a single transmembrane domain and a C-terminal intracellular kinase domain (de Caestecker 2004). In addition, towards the $\mathrm{N}$-terminus from the kinase domain, type I receptors contain a conserved GS domain (a sequence rich of glycine and serine residues) that is needed for phosphorylation (Shi \& Massague 2003, de Caestecker 2004). Both receptors are required for signalling, but the ligand specificity is mainly dictated by the type I receptor because it binds to the ligand with higher affinity than the type II receptor (Rosenzweig et al. 1995, ten Dijke et al. 2003). During ligand binding, a stable receptor complex is formed, which contains a receptor dimer of each type (Feng \& Derynck 2005). Constitutively, active type II receptors phosphorylate the GS domain of type I receptors, which in turn phosphorylate and thus activate downstream SMAD proteins (Feng \& Derynck 2005).

Different BMPs bind to the three type I receptors with different affinities (de Caestecker 2004). BMP2 tends to bind BMPR1A more than BMPR1B, BMP4 binds both with similar affinity, whereas BMP7 prefers ACVR1 and BMPR1B (Kawabata et al. 1998, Macias-Silva et al. 1998, ten Dijke et al. 2003, Sebald et al. 2004). More variation in receptor activation is provided in the complex formation. For example, BMP receptors BMPR1A, BMPR1B and BMPR2 can form oligomeric complexes with each other in any combination (Gilboa et al. 2000, Sebald et al. 2004). Furthermore, depending on the ligand, the receptor complex is formed in two alternative ways. BMP7 and BMP6 interact first with the type II receptor and then recruit type I receptors, whereas BMP2 and BMP4 bind first to the type I receptor and then recruit type II receptors (de Caestecker 2004). Finally, there is evidence that receptor complex formation can even affect the downstream signalling alternatives. If BMP binds to a preformed receptor complex, the Smad pathway is activated; in contrast, if complex formation occurs after BMP binding, the p38 mitogen-activated protein kinase (MAPK) pathway is activated (Nohe et al. 2002, 2004).

The major pathway for BMP signals is composed of intracellular SMAD proteins. BMP-specific receptors activate three R-SMADs (SMAD1, SMAD5 and SMAD8; Attisano \& Wrana 2000, Itoh et al. 2000, Derynck \& Zhang 2003). There is only one common SMAD (SMAD4), which is shared by all superfamily ligands (Derynck \& Zhang 2003). R-SMADs and 
SMAD4 are closely related; their structures are composed of two conserved, globular domains (Mad homology domain, $\mathrm{MH}$ ) that are joined together by a non-conserved linker domain (Massague et al. 2005). Upon activation, type I receptor phosphorylates a SXS motif of R-SMADs; thus, activated R-SMADs can interact with SMAD4, thereby forming a heteromeric complex that is translocated into the nucleus (ten Dijke et al. 2003, Feng \& Derynck 2005). It has been reported that BMP4 and GDF5 activate all three R-SMADs, whereas BMP6 and BMP7 activate only SMAD1 and SMAD5 (Aoki et al. 2001).

The SMAD complex interacts with specific DNA sequences called Smad-binding element or BMP response elements in the promoters or enhancers of target genes (Feng \& Derynck 2005). In fact, SMADs themselves have quite low affinity for DNA, and to obtain high affinity and target gene selectivity, numerous other factors co-operate with SMADs (ten Dijke et al. 2002, Feng \& Derynck 2005, Massague et al. 2005). Transcription factors that bind to adjacent promoters can either function in transcriptional activation or repression. For example, SMAD co-operating transcription factors include the Runx family of transcription factors, Menin, Hoxc-8, zinc finger proteins OAZ and YY1, and oestrogen receptor (ER; Hata et al. 2000, Zwijsen et al. 2003, Feng \& Derynck 2005, Miyazono et al. 2005). In addition, several nuclear co-activators (such as p300/CBP and GCN5) and co-repressors (such c-Ski, Sno, Tob, SIP1 and Evi-1) amplify and specify the signal response (von Bubnoff \& Cho 2001, Zwijsen et al. 2003, Feng \& Derynck 2005, Miyazono et al. 2005). The expression pattern and binding site preferences of these co-factors as well as their function in integration of cues from other signalling pathways all confer the specificity of target gene transcription (Schmierer \& Hill 2007).

In addition to the SMAD pathway, other intracellular pathways are activated in response to BMP ligands. For example, BMPs induce MAPK, but the exact mechanism of activation is not clear (Derynck \& Zhang 2003, Nohe et al. 2004, Javelaud \& Mauviel 2005). Studies in Xenopus laevis have indicated that BMP receptor activation leads to MAPK activation via $\mathrm{X}$-linked inhibitor of apoptosis, TGF $\beta$-activated kinase and Tak-binding protein (Shibuya et al. 1998, Yamaguchi et al. 1999, Herpin \& Cunningham 2007). BMP7 has been shown to induce p38 MAPK through integrin-linked kinases (Piscione et al. 2001, Hu et al. 2004, Leung-Hagesteijn et al. 2005). Furthermore, the ligands BMP2 and BMP4 can activate p38 and extracellular signal-related kinase (ERK) MAPK, but not JNK (Kimura et al. 2000, Nohe et al. 2002, 2004,
Jin et al. 2006, Otani et al. 2007, Yang et al. 2007b). MAPK can also modulate SMAD activation. Phosphorylation of the SMAD1 linker region in response to MAPK signalling can lead to attenuation of the BMP signal (Kretzschmar et al. 1997, Derynck \& Zhang 2003, Massague 2003, Sapkota et al. 2007). Besides MAPK, it has been reported that BMP2 can activate the protein kinase $\mathrm{C}$ and phosphatidylinositol 3-kinase pathways (Hay et al. 2001, Ghosh-Choudhury et al. 2002). BMPs are also known to crosstalk with other major signalling pathways, such as Wnt (Attisano \& Labbe 2004), JAK/STAT (von Bubnoff \& Cho 2001, Nohe et al. 2004, Miyazono et al. 2005) and Notch (Miyazono et al. 2005, Herpin \& Cunningham 2007).

At first glance, BMP signalling seems to function in a rather linear fashion. However, the considerable variation in the use of receptors, abundance of transcriptional co-regulators and links to other major pathways create more of a signalling network than a straight line.

\section{Regulation of the signalling pathway}

The BMP signalling pathway is heavily regulated at multiple levels. As discussed previously, diversity is achieved by heteromeric ligands, receptors, SMADs and their co-regulators, as well as other pathways. Furthermore, BMP signalling is adjusted by extracellular antagonists, accessory receptors on the membrane and intracellular control of SMAD activity.

Extracellularly, BMP ligands are inhibited by secreted peptides, called BMP antagonists (Gazzerro \& Canalis 2006). Antagonists can either bind the BMP ligand or BMP receptor to prevent ligand-receptor interaction (Balemans \& Van Hul 2002, Groppe et al. 2002, Canalis et al. 2003). Several different antagonists regulate different BMP activities, which include follistatin, noggin, the chordin family members, twisted gastrulation and DAN family members (such as gremlin, cerberus, dan and sclerostin; Reddi 2001, Balemans \& Van Hul 2002, Ebara \& Nakayama 2002, Canalis et al. 2003, Gazzerro \& Canalis 2006). Appropriate doses of extracellular BMP are ensured by feedback loops, because many of the antagonists themselves are target genes of BMPs (Miyazono 2000, Gazzerro \& Canalis 2006). Another level of regulation is provided by membrane-bound proteins. The antagonist-like function of the transmembrane protein CRIM1 prevents the actions of BMP7 and BMP4 already in the Golgi compartment by affecting ligand processing (Wilkinson et al. 2003). The pseudoreceptor BAMBI in turn interferes with the receptor complex, thus inhibiting BMP signalling 
(Onichtchouk et al. 1999, Canalis et al. 2003). There are also few membrane-bound peptides that can enhance BMP signalling, which include membraneanchored proteins DRAGON and RGMAa (repulsive guidance molecule) (Samad et al. 2005, Gazzerro \& Canalis 2006) and accessory receptors endoglin (Barbara et al. 1999, Scherner et al. 2007) and betaglycan (Kirkbride et al. 2008).

Intracellularly, BMP signalling is restrained by inhibitory SMADs (I-SMADs) and SMURF ubiquitin ligases (ten Dijke et al. 2002, Canalis et al. 2003, Massague et al. 2005). Two known I-SMADs, SMAD6 and SMAD7, are structurally similar to the R-SMADs. I-SMAD competes with R-SMAD in the interaction of activated type I receptors and with SMAD4 for the complex formation with SMAD1 (Massague et al. 2005). As with extracellular antagonists, I-SMADs are also BMP target genes, thus creating a feedback mechanism for BMP signals. SMURF1 and SMURF2 in turn target R-SMADs to degradation via the proteasome machinery resulting in BMP signalling inhibition (von Bubnoff \& Cho 2001, ten Dijke et al. 2002, Massague et al. 2005). In addition, SMURF1 directs BMP-specific receptors for degradation through interaction with I-SMADs (Murakami et al. 2003).

Some of the BMP target genes involved in bone induction and development are already known, and they include transcription factors (inhibitor of differentiation, Id), Runx2, MFH-1, Vent2, Msx2 and Dlx5, as well as antagonists and I-SMADs, which have already been mentioned (Canalis et al. 2003). Recent microarray-based studies have shown that expression levels of hundreds of genes are altered during osteoblastic differentiation (Balint et al. 2003, Korchynskyi et al. 2003, Peng et al. 2003, Gu et al. 2004, de Jong et al. 2004). Taking into account that BMPs function in diverse tissues at various phases of development, numerous different target genes can be expected. Only a part of these target genes are currently known, and several are still waiting to be discovered.

In normal tissues, there are several options to ensure proper spatiotemporal BMP signal that results in the desired phenotypic response. At the same time, this network of BMP signalling is highly sensitive to cancer-specific disturbances. Next, the role of BMP family members in breast cancer is discussed.

\section{Bone morphogenetic proteins in breast cancer}

Aberrant expression of the different BMP ligands has been detected in breast cancer (Table 1). We will first discuss the expression and possible functional significance of the different BMP ligands, for which BMP2, BMP6 and BMP7 are currently known best in breast cancer. There are only a few studies that have investigated the connection between BMP signalling and patient outcome, and most of the current knowledge of BMPs in breast cancer is based on in vitro and in vivo studies. In the last chapter, the connection between BMP signalling and the process of bone metastasis in breast cancer will be assessed.

\section{Expression and function}

\section{$B M P 2$}

BMP2 expression has been demonstrated in breast cancer, most often at low or similar levels as compared to normal cells. Transcripts of $B M P 2$ have been reported in a few breast cancer cell lines (Arnold et al. 1999, Clement et al. 2000, Schwaninger et al. 2007); however, based on a panel of 22 breast cancer cell lines, $B M P 2$ is expressed mainly at low levels in less than half of the cases (Alarmo et al. 2007). Similarly, significantly lower levels of $B M P 2$ were observed in both non-invasive and invasive breast tumours as well as in liver metastatic tumour tissues than in normal mammary gland samples, demonstrating that $B M P 2$ expression is downregulated in breast cancer (Reinholz et al. 2002). However, Clement et al. (2000) detected BMP2 expression in breast tumour specimens at similar levels than in the normal appearing cells in the tumour-free resection margin in the majority of patient samples. Here, it must be noted that such normal appearing adjacent tissues might contain cancer-specific alterations; and thus, they do not necessarily reflect the expression status of a truly normal tissue. Likewise, BMP2 expression was demonstrated in the majority of 39 primary tumour samples at very low and similar levels compared to normal mammary gland cDNA (Alarmo et al. 2007). Examination of BMP2 protein expression in breast cancer patient samples did not reveal any association with survival or clinicopathological parameters (Raida et al. 2005a). However, the antibody used in this study recognises both BMP2 and BMP4; and therefore, the individual ligand expression profiles could not be discerned.

Functionally, BMP2 is one of the most frequently studied ligands in breast cancer. BMP2 inhibits breast cancer cell proliferation (Ghosh-Choudhury et al. 2000a,b, Pouliot \& Labrie 2002). In these three functional studies, BMP2 was demonstrated to induce the level of p21 (a cyclin-dependent kinase inhibitor) and to cause the hypophosphorylation of the 
Table 1 Expression of bone morphogenetic protein (BMP) family members in breast cancer cell lines, primary tumours and recurrent tumours

\begin{tabular}{|c|c|c|c|c|c|c|c|c|c|}
\hline \multirow[b]{2}{*}{ Ligand } & \multirow[b]{2}{*}{ References } & \multirow[b]{2}{*}{ RNA/protein } & \multicolumn{2}{|c|}{ Cell line } & \multicolumn{2}{|c|}{$\begin{array}{l}\text { Primary } \\
\text { tumour }\end{array}$} & \multicolumn{2}{|c|}{ Recurrence } & \multirow{2}{*}{$\begin{array}{l}\text { Expression in tumour } \\
\text { samples }\end{array}$} \\
\hline & & & $\boldsymbol{F}$ & $n$ & $\boldsymbol{F}$ & $n$ & $\boldsymbol{F}$ & $n$ & \\
\hline \multirow[t]{5}{*}{ BMP2 } & Arnold et al. (1999) & $R N A$ & $100 \%$ & 2 & & & & & \\
\hline & Clement et al. (2000) & $R N A$ & $75 \%$ & 8 & $81 \%$ & 36 & & & $\begin{array}{l}\text { Similar expression } \\
\text { compared to tumour-free } \\
\text { resection margin }\end{array}$ \\
\hline & Reinholz et al. (2002) & $R N A$ & & & $100 \%$ & 29 & $100 \%$ & $5^{\mathrm{a}}$ & $\begin{array}{l}\text { Primaries and recurrences } \\
\text { downregulated } \\
\text { compared to } \\
18 \text { normal samples }\end{array}$ \\
\hline & Alarmo et al. (2007) & $R N A$ & $41 \%$ & 22 & $85 \%$ & 39 & & & \\
\hline & Schwaninger et al. (2007) & $R N A$ & $33 \%$ & 3 & & & & & \\
\hline \multirow[t]{3}{*}{ BMP3 } & Arnold et al. (1999) & $R N A$ & $100 \%$ & 2 & & & & & \\
\hline & Alarmo et al. (2007) & $R N A$ & $36 \%$ & 22 & $41 \%$ & 39 & & & \\
\hline & Schwaninger et al. (2007) & $R N A$ & $0 \%$ & 3 & & & & & \\
\hline \multirow[t]{3}{*}{ BMP4 } & Arnold et al. (1999) & $R N A$ & $0 \%$ & 2 & & & & & \\
\hline & Alarmo et al. (2007) & $R N A$ & $95 \%$ & 22 & $100 \%$ & 39 & & & \\
\hline & Schwaninger et al. (2007) & $R N A$ & $33 \%$ & 3 & & & & & \\
\hline \multirow[t]{2}{*}{ BMP5 } & Arnold et al. (1999) & $R N A$ & $100 \%$ & 2 & & & & & \\
\hline & Alarmo et al. (2007) & $R N A$ & $45 \%$ & 22 & $56 \%$ & 39 & & & \\
\hline \multirow[t]{6}{*}{ BMP6 } & Autzen et al. (1998) & $R N A$ & & & & & $60 \%$ & $5^{a}$ & \\
\hline & Arnold et al. (1999) & $R N A$ & $100 \%$ & 2 & & & & & \\
\hline & Clement et al. (1999) & $R N A$ & $100 \%$ & 5 & $100 \%$ & 44 & & & $\begin{array}{l}\text { Variable expression } \\
\text { compared to tumour-free } \\
\text { resection margin }\end{array}$ \\
\hline & Alarmo et al. (2007) & $R N A$ & $50 \%$ & 22 & $97 \%$ & 39 & & & \\
\hline & Schwaninger et al. (2007) & $R N A$ & $0 \%$ & 3 & & & & & \\
\hline & Zhang et al. (2007) & $R N A$ & $100 \%$ & 3 & & & & & \\
\hline \multirow[t]{6}{*}{ BMP7 } & Arnold et al. (1999) & $R N A$ & $0 \%$ & 2 & & & & & \\
\hline & Schwalbe et al. (2003) & Protein & $100 \%$ & 3 & $100 \%$ & 170 & & & \\
\hline & Alarmo et al. (2006) & Protein & $100 \%$ & 11 & $100 \%$ & 91 & & & $\begin{array}{l}\text { Upregulated compared to } \\
\text { ten normal samples }\end{array}$ \\
\hline & Alarmo et al. (2007) & $R N A$ & $82 \%$ & 22 & $100 \%$ & 39 & & & \\
\hline & Buijs et al. $(2007 a, b)$ & $R N A$ & & & $100 \%$ & 67 & & & \\
\hline & Alarmo et al. (2008) & Protein & & & $47 \%$ & 409 & $13 \%$ & $38^{b}$ & \\
\hline BMP8 & Alarmo et al. (2007) & $R N A$ & $95 \%$ & 22 & $77 \%$ & 39 & & & \\
\hline GDF9a & Hanavadi et al. (2007) & $R N A$ & $71 \%$ & 7 & $100 \%$ & 109 & & & $\begin{array}{l}\text { Upregulated compared to } \\
\text { non-neoplastic back- } \\
\text { ground tissue }(n=33)\end{array}$ \\
\hline BMP15 & Hanavadi et al. (2007) & $R N A$ & & & $100 \%$ & 109 & & & $\begin{array}{l}\text { Upregulated compared to } \\
\text { non-neoplastic back- } \\
\text { ground tissue }(n=33)\end{array}$ \\
\hline
\end{tabular}

$F$, frequency.

${ }^{a}$ Distant recurrence.

bocal recurrence.

retinoblastoma protein, resulting in $\mathrm{G}_{1}$ arrest of breast cancer cells. This growth arrest required both cytoplasmic signal transducers SMAD1 and SMAD4 (Pouliot \& Labrie 2002). Another study showed that the PTEN (a tumour suppressor) levels were increased in breast cancer cells after BMP2 treatment (Waite \& Eng 2003b). BMP2 can be influenced by other factors that affect breast cancer cell growth. Vitamin D is known to inhibit growth of breast cancer cells (Welsh 2007). BMP2 is upregulated in response to vitamin $D$ analogue treatment, which resulted in growth reduction of breast cancer cells (Lee et al. 2006a,b). Oestrogen is a well-known factor that regulates breast cancer cell proliferation, and it was shown to suppress BMP2 activity in one breast cancer cell line (Yamamoto et al. 2002). 
BMP2 reduces cancer cell growth, but it also has a beneficial impact on cancer cells. Breast cancer cell resistance to apoptosis is increased by BMP2, and based on microarray studies, BMP2 influences apoptosis-related genes (Raida et al. 2005a, Steinert et al. 2008). Furthermore, migration and invasion of breast cancer cells are enhanced by BMP2 (Clement et al. 2005). BMP2 also increases the endothelial cell tube formation in vitro, and BMP2 overexpressing MCF-7 breast cancer cells form tumours with pronounced vascularisation in a mouse xenograft model (Clement et al. 2005, Raida et al. 2005b). BMP2-induced endothelial cell activation was accompanied by increased p38 phosphorylation (Raida et al. 2005b). BMP2 can also influence tumour propagation in a more complex manner. BMP2 was shown to induce expression of tenascin-W, an extracellular matrix regulator that is found in the tumour stroma (Scherberich et al. 2005). In another study, BMP2 did not affect growth of tumours, but was able to initiate microcalcification in a rat breast tumour model (Liu et al. 2008). Although the functional significance of microcalcification is not yet clear, it is an important diagnostic marker because it is visible on mammograms of $30-50 \%$ of breast cancer patients.

To summarise, BMP2 expression is either downregulated or unaltered in breast cancer cells. Because BMP2 reduced cancer cell proliferation, it is reasonable to expect that it is downregulated in breast cancer. However, studies indicate that in certain contexts, BMP2 can also promote oncogenic behaviour by affecting apoptosis, migration, invasion and angiogenesis.

\section{BMP6}

BMP6 mRNA has also been detected in a few breast cancer cell lines (Arnold et al. 1999, Clement et al. 1999, Schwaninger et al. 2007, Yang et al. 2007a). A wide range of BMP6 expression levels have been reported in primary tumour samples with a minority of samples having elevated levels compared to normal appearing cells in the tumour resection margin (Clement et al. 1999). In a set of 22 breast cancer cell lines and 39 primary tumours, BMP6 was expressed mainly at rather low levels (Alarmo et al. 2007). BMP6 expression is associated with E-cadherin expression, which links it to non-invasive breast cancer phenotypes (Yang et al. 2007a). Interestingly, BMP6 transcripts have been detected in breast cancer skeletal metastases (Autzen et al. 1998). An epigenetic mechanism might be involved in the regulation of expression because BMP6 hypermethylation and inactivation were detected in breast cancer patient samples (Zhang et al. 2007). Hypermethylation was seen only in ER-negative breast tumours, but not in ER-positive tumours. Oestrogen has been shown to induce as well as inhibit BMP6 expression in breast cancer cells (Ong et al. 2004, Zhang et al. 2005, Takahashi et al. 2008). Vitamin D and epidermal growth factor (EGF) have also been shown to stimulate BMP6 expression in a few breast cancer cell lines (Clement et al. 1999, Lee et al. 2006a,b).

BMP6 function in breast cancer has been studied mainly in a few breast cancer cell lines where it inhibits growth and migration of cancer cells. Combined treatment with BMP6 and oestrogen inhibits growth of MCF-7 breast cancer cells and reduces p38 MAPK activity; however, BMP6 alone did not affect growth of these cells (Takahashi et al. 2008). BMP6 attenuates MDA-MB-231 breast cancer cell migration by regulating expression of the transcriptional repressor zinc finger E-box binding homeobox 1 (ZEB1), also known as $\delta E F 1$; Yang et al. 2009). BMP6 inhibits ZEB1 expression by repressing the promoter as well as by increasing miR-192 expression, which subsequently downregulates ZEB1 (Yang et al. 2009). Reduced ZEB1 expression in turn results in decreased miR-21 expression, an miRNA implicated in invasion and metastasis (Du et al. 2009). BMP6 treatment also reduced MDA-MB-231 cell proliferation, but still protected these cells from apoptosis, demonstrating a dual function for BMP6 in breast cancer (Du et al. 2007).

Taken together, BMP6 expression in breast cancer does not dramatically differ from the patterns seen in normal cells, but interestingly, BMP6 inactivation by hypermethylation has been detected in ER-negative breast cancer patients. Functional studies have mostly revealed the cancer-inhibiting properties of BMP6. These mechanisms are often rather complex in nature, and they also involve miRNAs.

\section{$B M P 7$}

$B M P 7$ transcripts have been detected with highly variable expression levels in tumour samples (Alarmo et al. 2006, Buijs et al. 2007a). The expression of BMP family members has rarely been studied at the protein level in breast cancer, and BMP7 is the only ligand that has been reasonably well studied in patient samples. BMP7 protein expression was first reported in 3 breast cancer cell lines, 170 primary breast tumours and 1 normal mammary gland sample (Schwalbe et al. 2003). In this set of primary tumours, BMP7 protein expression levels were highly variable but were 
associated with hormone receptor status. Similarly, frequent BMP7 expression was detected in 11 breast cancer cell lines and in primary breast tumour samples $(n=91$; Alarmo et al. 2006). The majority of the patient samples demonstrated BMP7 overexpression compared to ten normal mammary gland samples (Alarmo et al. 2006). We also found that BMP7 is not an amplification target gene even though it resides in the chromosomal area 20q13, which is frequently amplified in breast cancer (Kallioniemi et al. 1994, Hodgson et al. 2003). Amplification is a common mechanism of oncogene activation in solid tumours (Albertson et al. 2003, Albertson 2006). A follow-up study using a substantially larger set $(n=409)$ of patient samples also identified BMP7 overexpression in half of the samples (Alarmo et al. 2008).

We have shown that BMP7 protein expression in primary tumours is associated with accelerated bone metastasis formation, and BMP7 expression was further shown to be an independent prognostic factor for early bone metastasis (Alarmo et al. 2008). Interestingly, BMP7 expression is often lost in the corresponding local recurrent tumour (Alarmo et al. 2008). In another patient series, the median $B M P 7$ transcript level in primary tumours was higher in patients with visceral rather than bone metastases, but not significantly different in patients with or without metastasis (Buijs et al. 2007a).

The functional significance of BMP7 has been studied in breast cancer cell line models where different phenotypes were observed after BMP7 manipulation by siRNA-based silencing or BMP7 treatment (Alarmo et al. 2009). BMP7 was shown to stimulate growth of two breast cancer cell lines and inhibit growth of four cell lines. In addition, exogenous BMP7 significantly increased the migration and invasion of MDA-MB-231 cells in vitro (Alarmo et al. 2009). On the contrary, in a MDA-MB-231 xenograft mouse model, exogenous BMP7 was shown to decrease tumour growth (Buijs et al. 2007a). Buijs et al. (2007a) also showed that endogenous and exogenous BMP7 treatment results in diminished formation and growth of bone metastases.

Different phenotypic responses to BMP7 could be due to other factors that have an impact on BMP7 expression or activity. BMP7 was identified as a novel target gene for Lim only protein 4 , which is frequently overexpressed in breast cancer (especially in ER-negative tumours) and is associated with poor outcome (Wang et al. 2007). A recent study also revealed that BMP7 is a direct target gene for the p53 family of proteins (Yan \& Chen 2007). This study showed that in a p53 mutant breast cancer cell line,
BMP7 reduction leads to decreased growth, whereas in a p53 wild-type breast cancer cell line, no growth reduction was detected. Hence, BMP7 could function to maintain cell survival in p53-deficient breast cancer cells (Yan \& Chen 2007). BMP7 expression has been shown to diminish in response to oestrogen (Kusumegi et al. 2004, Takahashi et al. 2008). Similarly to BMP6, BMP7 and oestrogen together inhibit MCF-7 proliferation, but BMP7 alone does not alter cell growth (Takahashi et al. 2008).

To conclude, BMP7 is widely expressed in breast cancer and is associated with early bone metastasis. Several factors seem to influence the expression or activity of BMP7. This might explain that phenotypes supporting both cancer progression and regression have been described after manipulation of BMP7 signalling.

\section{Other BMP ligands}

The role of the other BMP family ligands in breast cancer has been studied less intensively. The expression levels of GDF9a and BMP15 are downregulated in breast tumours compared to normal samples, and diminished transcript expression of these genes is associated with poor prognosis (Hanavadi et al. 2007). Transcripts of $B M P 3, B M P 4, B M P 5$ and $B M P 8$ have been reported only in a few breast cancer cell lines (Arnold et al. 1999, Clement et al. 2000, Schwaninger et al. 2007). An expression survey using 22 breast cancer cell lines and 39 primary breast tumours revealed that among these ligands, BMP4 had a very prominent profile, and it was overexpressed in the majority of cell lines and tumour samples (Alarmo et al. 2007, Ketolainen et al. 2010). BMP3 and BMP5 were detected, but at more modest expression frequencies and levels, and $B M P 8$, although it was frequently detected, clearly at lower levels (Alarmo et al. 2007).

There are only a few functional studies that have concentrated on ligands other than BMP2, BMP6 or BMP7. BMP4 has been suggested to promote invasive behaviour of mammary epithelial cells, and thus also cancerous cells because it disturbs the formation of the lumen of mammary epithelial cells (Montesano 2007). In another study, it reduced migration and invasion of breast cancer cells in vitro and suppressed matrix metallopeptidase (MMP-9) expression, thereby inhibiting invasive behaviour (Shon et al. 2009). BMP4 expression was shown to be dependent on $N$-myc downstream-regulated gene 2 (NDRG2) overexpression (Shon et al. 2009). The same dependency on other factors was detected when BMP4 stimulated immortalised murine mammary epithelial cell proliferation in 
combination with different other cytokines (fibroblast growth factor (FGF)-2, FGF-7, FGF-10, EGF and hepacyte growth factor (HGF)) but not alone (Montesano et al. 2008). In a recent work done by Ketolainen et al. (2010), BMP4 treatment decreased growth of nine breast cancer cell lines studied by inducing a $G_{1}$ arrest. Interestingly, at the same time, BMP4 increases migration and invasion of a subset of these cell lines, demonstrating a truly dualistic function for BMP4 in breast cancer cells (Ketolainen et al. 2010).

\section{$B M P$ receptors and $B M P$ signalling components}

The expression profiles of BMP-specific receptors have been rather infrequently studied. We showed that type I (BMPRIA, BMPRIB and ACVRI) and type II (BMPR2, $A C V R 2 A$ and $A C V R 2 B$ ) BMP-specific receptor transcripts were detected in a comparably more uniform manner than the ligands in all breast cancer cell lines and primary tumour samples studied (Alarmo et al. 2007). Helms et al. (2005) demonstrated that BMPR1B is overexpressed in breast cancer, and that it is associated with poor prognosis of breast cancer patients. BMPR1B expression in ER-positive breast cancer specimens correlates with high tumour grade, high tumour proliferation index and cytogenetic instability (Helms et al. 2005). In addition, BMPR1B expression is accompanied by SMAD1/5/8 activation as well as anti-apoptotic activity, linking active BMP signalling to tumour progression (Helms et al. 2005). Similarly, phosphorylated SMAD1/5/8 protein was detected in primary breast tumours, lymph node and bone metastases (Katsuno et al. 2008). In their study, expression of a dominant negative BMPR1A in a mouse xenograft model resulted in decreased invasiveness and bone metastasis, as well as prolonged survival of the mice (Katsuno et al. 2008). Blocking active BMP signalling in vitro using a dominant negative form of BMPR2 receptor instead of BMPR1A was shown to lead to growth reduction of breast cancer cells (Pouliot et al. 2003). Thus, depending on the receptor, BMP signalling is able to modulate cell growth or invasion.

As discussed above, several factors can modulate the activity of both BMP ligands and other pathway components. Oestrogen was shown to reduce the mRNA levels of BMP-specific receptors (Takahashi et al. 2008). In addition to upregulation of $B M P 2$ and $B M P 6$, vitamin D reduced SMAD6 expression and resulted in SMAD1/5 phosphorylation, implicating that vitamin D can mediate growth inhibitory effects through active BMP signalling in breast cancer (Lee et al. 2006a,b). Variable BMP functions could also be a result of alternative pathway activation, which has been detected at least with the ligands BMP2, BMP4 and BMP6. MAPK activation was seen in BMP4-induced disruption of the mammary epithelial lumen as well as BMP2-induced endothelial cell activation in breast cancer (Raida et al. 2005b, Montesano 2007). Both SMAD and p38 MAPK pathways were shown to be activated in breast cancer cells in response to BMP6-induced anti-apoptotic effect (Du et al. 2007). Interpretation of BMP function in breast cancer can be further complicated by the involvement of stromal cells in mammary tumourigenesis. Sneddon et al. (2006) detected elevated levels of GREMLIN 1 in breast tumour stroma, and suggested a model where BMP antagonists produced by the tumour stroma maintain tumour cell expansion, analogous to the stem cell expansion in the normal tissues.

Compared to the amount of studies concentrating on BMP ligands, there are only few studies that have focused on BMP-specific receptors or other BMP signalling pathway components in breast cancer. Whereas BMP ligands produce alternating phenotypes in breast cancer cells, thus far, BMP-specific receptors seem more likely to stimulate cancer progression.

\section{BMPs and bone metastasis}

A natural focus for BMP research in cancer is their possible involvement in the process of bone metastases. Cancers originating in the epithelia of breast and prostate tissues are particularly known to frequently metastasise to the bone. Studies in prostate cancer suggest that BMP signalling plays an active role in this process (Keller et al. 2001, Vessella \& Corey 2006, Ye et al. 2007). In breast cancer, fewer studies have examined the contribution of BMPs to bone metastases.

BMP-regulated factors have been suggested to be involved in bone metastasis. Breast cancer cell linederived BMPs were shown to upregulate bone sialoprotein (BSP) expression in preosteoblast cells (Bunyaratavej et al. 2000). BSP is involved in new bone formation and could therefore provide a link between the metastatic process to bone and breast cancer. A known BMP target gene and a co-factor for BMP signalling, RUNX2, might be another such link. Intact RUNX2 is required for the formation of breast cancer osteolytic metastases in bones (Barnes et al. 2004, Javed et al. 2005). Schwaninger et al. (2007) showed that forced expression of the BMP antagonist noggin in osteoinductive (osteoblastic bone metastases forming) prostate cancer cells in vivo diminishes the 
osteoblastic response in bone (i.e. no excess bone formation and reduced number of osteoclasts). However, noggin overexpression does not affect the tumour growth in this intraosseous xenograft model. Because noggin was not expressed in osteoinductive prostate or breast cancer cell lines, this implies that even though active BMP signalling does not affect tumour growth, it might contribute to the formation of osteoblastic bone metastases by changing the bone architecture (Schwaninger et al. 2007).

Recent work of Buijs et al. (2007a) has shown that overexpression of BMP7 as well as exogenous BMP7 treatment significantly reduces the formation of bone metastases and growth in a mouse xenograft model of breast cancer. They detected BMP7 expression in breast cancer cell lines with a more epithelial than invasive phenotype (high E-cadherin expression and low vimentin expression; Buijs et al. 2007a). BMP7 has been shown to reverse TGF $\beta$-induced EMT by decreasing vimentin expression and increasing E-cadherin expression in breast cancer cells and in normal mouse mammary epithelial cells (Zeisberg et al. 2003, Valcourt et al. 2005, Buijs et al. 2007a). Kowanetz et al. (2004) showed that increased E-cadherin expression occurs through BMP7-induced upregulation of Id 2 and Id3. Interestingly, when Id2-3 is knocked out, BMP7 actually induces the smooth muscle actin (SMA), a mesenchymal phenotype marker) expression and stimulates EMT in mouse mammary epithelial cells (Kowanetz et al. 2004, Valcourt et al. 2005). These studies illustrate well the complex network of proteins that are involved in BMP-regulated cellular processes.

In contrast to the results of Buijs et al. (2007a), a recent study using a similar mouse xenograft model of breast cancer has showed that active BMP signalling actually increases invasion and bone metastases (Katsuno et al. 2008). They detected activated SMAD1/5/8 in primary and metastatic tumours, and utilised functional bioluminescence imaging to demonstrate that BMP signalling results in transcriptional activity in bone metastases in vivo. Inhibition of BMP signalling through the dominant negative BMPR1A reduces interleukin-11 expression and invasiveness in vitro and bone metastasis in vivo, and it resulted in prolonged survival of the mice (Katsuno et al. 2008). As discussed earlier, BMP ligands bind their receptors with different affinities (Sebald et al. 2004). For example, BMPR1A is preferred by BMP2 and BMP4 instead of BMP7; thus, the discrepancy in the work done by Buijs et al. might be partly explained by the receptor. However, we observed that BMP7 expression is associated with accelerated bone metastasis formation and acted as an independent prognostic factor for early bone metastases (Alarmo et al. 2008).

\section{Conclusions}

BMPs have diverse cancer-specific expression patterns that differ from the expression patterns observed in normal mammary tissues, indicating aberrant behaviour in breast cancer. Common receptor expression in breast cancer also indicates that BMP signalling is not restrained, which is sometimes seen in some inheritable cancer syndromes. These expression patterns vary when different cancer types are compared. Contrary to breast cancer, BMP2 is overexpressed in virtually every lung cancer (Langenfeld et al. 2005), and BMP7 is downregulated in prostate cancer (Masuda et al. 2004, Buijs et al. 2007b). Similarly, BMPR1A, BMPR1B and BMPR2 expression has been shown to be lost in advanced prostate cancer (Kim et al. 2000, 2004), but such a phenomenon has not been observed in breast cancer (Alarmo et al. 2007). One can reasonably expect that diverse expression profiles also lead to diverse phenotypic effects depending on the cancer type in question.

The main theme in the functional studies of BMPs in breast cancer is that the same ligand can both promote and inhibit cancer progression depending on the study. Many of the in vitro or in vivo studies rely on a single cell line; thus, it is difficult to ascertain how well the results can be generalised. We showed that among eight breast cancer cell lines, BMP7 stimulated growth in two, inhibited growth in four, and two cell lines did not respond to BMP7 at all (Alarmo et al. 2009). Similarly, in prostate cancer, BMP7 elicits diverse functional responses depending on the cell line (Yang et al. 2005). Therefore, conclusions based simply on one cell line might be too straightforward. It is thus highly important to use large, unbiased patient materials to explore the possible impact of particular BMPs in a comprehensive manner.

BMP-inducible phenotypes in breast cancer clearly seem to be context dependent as can be expected based on the heavily regulated signalling pathway discussed in the beginning of this review. Some studies have detected that other growth factors and hormones alter the response to BMP. Oestrogen, an important hormonal player in breast cancer (Anderson 2002), modulates BMP ligands themselves as well as the responses elicited by BMPs. ER is also a known transcription factor operating with SMADs. 
More detailed analysis on BMP signalling and its regulation in tumourigenesis is obviously needed to clarify the impact of BMPs in breast cancer. Whether the seeming discrepancy of results between studies is actually a reflection of bidirectionality remains to be seen. BMP2, BMP4 and BMP7 have been shown to both inhibit and promote breast cancer progression; thus, they possess bidirectional functions similar to the dual role established for TGF $\beta$ in breast cancer.

As a whole, despite the fact that a great number of the studies on BMPs in cancer have concentrated on breast carcinomas, a systematic view on the actions of BMPs in breast cancer is still developing. These studies illustrate that the pleiotropy BMPs exert in normal tissues is also possible in cancer. The naturally occurring extra- and intracellular inhibitors of BMP signalling will eventually offer a plethora of therapeutic intervention points and might allow fine tuning of therapeutic options in breast cancer (Tsuchida et al. 2006, Gazzerro \& Minetti 2007). Even though at this time solid conclusions are hard to draw due to conflicting results, BMPs are no doubt significant players in the breast cancer development, and the future challenge will be to find out what brings the worst out of BMPs.

\section{Declaration of interest}

The authors declare that there is no conflict of interest that could be perceived as prejudicing the impartiality of the research reported.

\section{Funding}

This work was partly supported by the grants from the Sigrid Juselius Foundation and the Medical Research Fund of the Tampere University Hospital.

\section{References}

Alarmo EL, Rauta J, Kauraniemi P, Karhu R, Kuukasjarvi T \& Kallioniemi A 2006 Bone morphogenetic protein 7 is widely overexpressed in primary breast cancer. Genes, Chromosomes and Cancer 45 411-419.

Alarmo EL, Kuukasjarvi T, Karhu R \& Kallioniemi A 2007 A comprehensive expression survey of bone morphogenetic proteins in breast cancer highlights the importance of BMP4 and BMP7. Breast Cancer Research and Treatment 103 239-246.

Alarmo EL, Korhonen T, Kuukasjarvi T, Huhtala H, Holli K \& Kallioniemi A 2008 Bone morphogenetic protein 7 expression associates with bone metastasis in breast carcinomas. Annals of Oncology 19 308-314.
Alarmo EL, Parssinen J, Ketolainen JM, Savinainen K, Karhu R \& Kallioniemi A 2009 BMP7 influences proliferation, migration, and invasion of breast cancer cells. Cancer Letters 275 35-43.

Albertson DG 2006 Gene amplification in cancer. Trends in Genetics 22 447-455.

Albertson DG, Collins C, McCormick F \& Gray JW 2003 Chromosome aberrations in solid tumors. Nature Genetics 34 369-376.

Anderson E 2002 The role of oestrogen and progesterone receptors in human mammary development and tumorigenesis. Breast Cancer Research 4 197-201.

Aoki H, Fujii M, Imamura T, Yagi K, Takehara K, Kato M \& Miyazono K 2001 Synergistic effects of different bone morphogenetic protein type I receptors on alkaline phosphatase induction. Journal of Cell Science 114 1483-1489.

Aono A, Hazama M, Notoya K, Taketomi S, Yamasaki H, Tsukuda R, Sasaki S \& Fujisawa Y 1995 Potent ectopic bone-inducing activity of bone morphogenetic protein-4/7 heterodimer. Biochemical and Biophysical Research Communications 210 670-677.

Arnold SF, Tims E \& Mcgrath BE 1999 Identification of bone morphogenetic proteins and their receptors in human breast cancer cell lines: importance of BMP2. Cytokine 11 1031-1037.

Attisano L \& Labbe E 2004 TGF $\beta$ and Wnt pathway cross-talk. Cancer Metastasis Reviews 23 $53-61$.

Attisano L \& Wrana JL 2000 Smads as transcriptional co-modulators. Current Opinion in Cell Biology 12 235-243.

Autzen P, Robson CN, Bjartell A, Malcolm AJ, Johnson MI, Neal DE \& Hamdy FC 1998 Bone morphogenetic protein 6 in skeletal metastases from prostate cancer and other common human malignancies. British Journal of Cancer 78 1219-1223.

Balemans W \& Van Hul W 2002 Extracellular regulation of BMP signaling in vertebrates: a cocktail of modulators. Developmental Biology $250231-250$.

Balint E, Lapointe D, Drissi H, van der Meijden C, Young DW, van Wijnen AJ, Stein JL, Stein GS \& Lian JB 2003 Phenotype discovery by gene expression profiling: mapping of biological processes linked to BMP-2-mediated osteoblast differentiation. Journal of Cellular Biochemistry 89 401-426.

Barbara NP, Wrana JL \& Letarte M 1999 Endoglin is an accessory protein that interacts with the signaling receptor complex of multiple members of the transforming growth factor- $\beta$ superfamily. Journal of Biological Chemistry 274 584-594.

Barnes GL, Hebert KE, Kamal M, Javed A, Einhorn TA, Lian JB, Stein GS \& Gerstenfeld LC 2004 Fidelity of Runx 2 activity in breast cancer cells is required for the generation of metastases-associated osteolytic disease. Cancer Research 64 4506-4513. 
Bleuming SA, He XC, Kodach LL, Hardwick JC, Koopman FA, Ten Kate FJ, van Deventer SJ, Hommes DW, Peppelenbosch MP, Offerhaus GJ et al. 2007 Bone morphogenetic protein signaling suppresses tumorigenesis at gastric epithelial transition zones in mice. Cancer Research 67 8149-8155.

Botchkarev VA 2003 Bone morphogenetic proteins and their antagonists in skin and hair follicle biology. Journal of Investigative Dermatology 120 36-47.

von Bubnoff A \& Cho KW 2001 Intracellular BMP signaling regulation in vertebrates: pathway or network? Developmental Biology 239 1-14.

Buijs JT, Henriquez NV, van Overveld PG, van der Horst G, Que I, Schwaninger R, Rentsch C, ten Dijke P, Cleton-Jansen AM, Driouch K et al. 2007a Bone morphogenetic protein 7 in the development and treatment of bone metastases from breast cancer. Cancer Research 67 8742-8751.

Buijs JT, Rentsch CA, van der Horst G, van Overveld PG, Wetterwald A, Schwaninger R, Henriquez NV, ten Dijke P, Borovecki F, Markwalder R et al. 2007b BMP7, a putative regulator of epithelial homeostasis in the human prostate, is a potent inhibitor of prostate cancer bone metastasis in vivo. American Journal of Pathology 171 1047-1057.

Bunyaratavej P, Hullinger TG \& Somerman MJ 2000 Bone morphogenetic proteins secreted by breast cancer cells upregulate bone sialoprotein expression in preosteoblast cells. Experimental Cell Research 260 324-333.

de Caestecker M 2004 The transforming growth factor- $\beta$ superfamily of receptors. Cytokine and Growth Factor Reviews 15 1-11.

Canalis E, Economides AN \& Gazzerro E 2003 Bone morphogenetic proteins, their antagonists, and the skeleton. Endocrine Reviews 24 218-235.

Chang H, Brown CW \& Matzuk MM 2002 Genetic analysis of the mammalian transforming growth factor- $\beta$ superfamily. Endocrine Reviews 23 787-823.

Cheng KH, Ponte JF \& Thiagalingam S 2004 Elucidation of epigenetic inactivation of SMAD8 in cancer using targeted expressed gene display. Cancer Research 64 1639-1646.

Cho KW, Kim JY, Song SJ, Farrell E, Eblaghie MC, Kim HJ, Tickle C \& Jung HS 2006 Molecular interactions between Tbx 3 and Bmp4 and a model for dorsoventral positioning of mammary gland development. PNAS 103 16788-16793.

Clement JH, Sanger J \& Hoffken K 1999 Expression of bone morphogenetic protein 6 in normal mammary tissue and breast cancer cell lines and its regulation by epidermal growth factor. International Journal of Cancer $\mathbf{8 0}$ 250-256.

Clement JH, Marr N, Meissner A, Schwalbe M, Sebald W, Kliche KO, Hoffken K \& Wolfl S 2000 Bone morphogenetic protein 2 (BMP-2) induces sequential changes of Id gene expression in the breast cancer cell line MCF-7. Journal of Cancer Research and Clinical Oncology 126 271-279.
Clement JH, Raida M, Sanger J, Bicknell R, Liu J, Naumann A, Geyer A, Waldau A, Hortschansky P, Schmidt A et al. 2005 Bone morphogenetic protein 2 (BMP-2) induces in vitro invasion and in vivo hormone independent growth of breast carcinoma cells. International Journal of Oncology 27 401-407.

Constam DB \& Robertson EJ 1999 Regulation of bone morphogenetic protein activity by pro domains and proprotein convertases. Journal of Cell Biology 144 139-149.

Deng H, Makizumi R, Ravikumar TS, Dong H, Yang W \& Yang WL 2007 Bone morphogenetic protein-4 is overexpressed in colonic adenocarcinomas and promotes migration and invasion of HCT116 cells. Experimental Cell Research 313 1033-1044.

Derynck R \& Zhang YE 2003 Smad-dependent and Smad-independent pathways in TGF- $\beta$ family signalling. Nature 425 577-584.

Derynck R, Akhurst RJ \& Balmain A 2001 TGF- $\beta$ signaling in tumor suppression and cancer progression. Nature Genetics 29 117-129.

ten Dijke P \& Hill CS 2004 New insights into TGF- $\beta$-Smad signalling. Trends in Biochemical Sciences 29 265-273.

ten Dijke P, Goumans MJ, Itoh F \& Itoh S 2002 Regulation of cell proliferation by Smad proteins. Journal of Cellular Physiology 191 1-16.

ten Dijke P, Korchynskyi O, Valdimarsdottir G \& Goumans MJ 2003 Controlling cell fate by bone morphogenetic protein receptors. Molecular and Cellular Endocrinology 211 105-113.

Du J, Yang S, Wang Z, Zhai C, Yuan W, Lei R, Zhang J \& Zhu T 2007 Bone morphogenetic protein 6 inhibit stress-induced breast cancer cells apoptosis via both smad and P38 pathways. Journal of Cellular Biochemistry 103 1584-1597.

Du J, Yang S, An D, Hu F, Yuan W, Zhai C \& Zhu T 2009 BMP-6 inhibits microRNA-21 expression in breast cancer through repressing deltaEF1 and AP-1. Cell Research 19 487-496.

Ducy P \& Karsenty G 2000 The family of bone morphogenetic proteins. Kidney International 57 2207-2214.

Ebara S \& Nakayama K 2002 Mechanism for the action of bone morphogenetic proteins and regulation of their activity. Spine 27 S10-S15.

Feng XH \& Derynck R 2005 Specificity and versatility in tgf- $\beta$ signaling through Smads. Annual Review of Cell and Developmental Biology 21 659-693.

Gazzerro E \& Canalis E 2006 Bone morphogenetic proteins and their antagonists. Reviews in Endocrine and Metabolic Disorders 7 51-65.

Gazzerro E \& Minetti C 2007 Potential drug targets within bone morphogenetic protein signaling pathways. Current Opinion in Pharmacology 7 325-333. 
Ghosh-Choudhury N, Ghosh-Choudhury G, Celeste A, Ghosh PM, Moyer M, Abboud SL \& Kreisberg J $2000 a$ Bone morphogenetic protein-2 induces cyclin kinase inhibitor p21 and hypophosphorylation of retinoblastoma protein in estradiol-treated MCF-7 human breast cancer cells. Biochimica et Biophysica Acta 1497 186-196.

Ghosh-Choudhury N, Woodruff K, Qi W, Celeste A, Abboud SL \& Ghosh Choudhury G $2000 b$ Bone morphogenetic protein-2 blocks MDA MB 231 human breast cancer cell proliferation by inhibiting cyclin-dependent kinase-mediated retinoblastoma protein phosphorylation. Biochemical and Biophysical Research Communications 272 705-711.

Ghosh-Choudhury N, Abboud SL, Nishimura R, Celeste A, Mahimainathan L \& Choudhury GG 2002 Requirement of BMP-2-induced phosphatidylinositol 3-kinase and Akt serine/threonine kinase in osteoblast differentiation and Smad-dependent BMP-2 gene transcription. Journal of Biological Chemistry 277 33361-33368.

Gilboa L, Nohe A, Geissendorfer T, Sebald W, Henis YI \& Knaus P 2000 Bone morphogenetic protein receptor complexes on the surface of live cells: a new oligomerization mode for serine/threonine kinase receptors. Molecular Biology of the Cell 11 1023-1035.

Gregory KE, Ono RN, Charbonneau NL, Kuo CL, Keene DR, Bachinger HP \& Sakai LY 2005 The prodomain of BMP-7 targets the BMP-7 complex to the extracellular matrix. Journal of Biological Chemistry 280 27970-27980.

Griffith DL, Keck PC, Sampath TK, Rueger DC \& Carlson WD 1996 Three-dimensional structure of recombinant human osteogenic protein 1: structural paradigm for the transforming growth factor $\beta$ superfamily. PNAS 93 878-883.

Groppe J, Greenwald J, Wiater E, Rodriguez-Leon J, Economides AN, Kwiatkowski W, Affolter M, Vale WW, Belmonte JC \& Choe S 2002 Structural basis of BMP signalling inhibition by the cystine knot protein Noggin. Nature 420 636-642.

Gu K, Zhang L, Jin T \& Rutherford RB 2004 Identification of potential modifiers of Runx2/Cbfa1 activity in $\mathrm{C} 2 \mathrm{C} 12$ cells in response to bone morphogenetic protein-7. Cells, Tissues, Organs 176 28-40.

Hanavadi S, Martin TA, Watkins G, Mansel RE \& Jiang WG 2007 The role of growth differentiation factor-9 (GDF-9) and its analog, GDF-9b/BMP-15, in human breast cancer. Annals of Surgical Oncology 14 2159-2166.

Harradine KA \& Akhurst RJ 2006 Mutations of TGF $\beta$ signaling molecules in human disease. Annals of Medicine 38 403-414.

Hata A, Seoane J, Lagna G, Montalvo E, Hemmati-Brivanlou A \& Massague J 2000 OAZ uses distinct DNA- and protein-binding zinc fingers in separate BMP-Smad and Olf signaling pathways. Cell 100 229-240.
Hay E, Lemonnier J, Fromigue O \& Marie PJ 2001 Bone morphogenetic protein-2 promotes osteoblast apoptosis through a Smad-independent, protein kinase C-dependent signaling pathway. Journal of Biological Chemistry 276 29028-29036.

Heldin CH, Miyazono K \& ten Dijke P 1997 TGF- $\beta$ signalling from cell membrane to nucleus through SMAD proteins. Nature 390 465-471.

Helms MW, Packeisen J, August C, Schittek B, Boecker W, Brandt BH \& Buerger H 2005 First evidence supporting a potential role for the BMP/SMAD pathway in the progression of oestrogen receptor-positive breast cancer. Journal of Pathology 206 366-376.

Herpin A \& Cunningham C 2007 Cross-talk between the bone morphogenetic protein pathway and other major signaling pathways results in tightly regulated cell-specific outcomes. FEBS Journal 274 2977-2985.

Hodgson JG, Chin K, Collins C \& Gray JW 2003 Genome amplification of chromosome 20 in breast cancer. Breast Cancer Research and Treatment 78 337-345.

Hogan BL 1996 a Bone morphogenetic proteins: multifunctional regulators of vertebrate development. Genes and Development 10 1580-1594.

Hogan BL $1996 b$ Bone morphogenetic proteins in development. Current Opinion in Genetics \& Development 6 432-438.

Hsu MY, Rovinsky S, Penmatcha S, Herlyn M \& Muirhead D 2005 Bone morphogenetic proteins in melanoma: angel or devil? Cancer Metastasis Reviews 24 251-263.

Hu MC, Wasserman D, Hartwig S \& Rosenblum ND 2004 p38MAPK acts in the BMP7-dependent stimulatory pathway during epithelial cell morphogenesis and is regulated by Smad1. Journal of Biological Chemistry 279 12051-12059.

Israel DI, Nove J, Kerns KM, Kaufman RJ, Rosen V, Cox KA \& Wozney JM 1996 Heterodimeric bone morphogenetic proteins show enhanced activity in vitro and in vivo. Growth Factors 13 291-300.

Itoh S, Itoh F, Goumans MJ \& ten Dijke P 2000 Signaling of transforming growth factor- $\beta$ family members through Smad proteins. European Journal of Biochemistry $\mathbf{2 6 7}$ 6954-6967.

Javed A, Barnes GL, Pratap J, Antkowiak T, Gerstenfeld LC, van Wijnen AJ, Stein JL, Lian JB \& Stein GS 2005 Impaired intranuclear trafficking of Runx2 (AML3/CBFA1) transcription factors in breast cancer cells inhibits osteolysis in vivo. PNAS $\mathbf{1 0 2}$ 1454-1459.

Javelaud D \& Mauviel A 2005 Crosstalk mechanisms between the mitogen-activated protein kinase pathways and Smad signaling downstream of TGF- $\beta$ : implications for carcinogenesis. Oncogene 24 5742-5750.

Jin EJ, Lee SY, Choi YA, Jung JC, Bang OS \& Kang SS 2006 BMP-2-enhanced chondrogenesis involves p38 MAPK-mediated down-regulation of Wnt-7a pathway. Molecules and Cells 22 353-359. 
de Jong DS, Vaes BL, Dechering KJ, Feijen A, Hendriks JM, Wehrens R, Mummery CL, van Zoelen EJ, Olijve W \& Steegenga WT 2004 Identification of novel regulators associated with early-phase osteoblast differentiation. Journal of Bone and Mineral Research 19 947-958.

Kallioniemi A, Kallioniemi OP, Piper J, Tanner M, Stokke T, Chen L, Smith HS, Pinkel D, Gray JW \& Waldman FM 1994 Detection and mapping of amplified DNA sequences in breast cancer by comparative genomic hybridization. PNAS 91 2156-2160.

Katsuno Y, Hanyu A, Kanda H, Ishikawa Y, Akiyama F, Iwase T, Ogata E, Ehata S, Miyazono K \& Imamura T 2008 Bone morphogenetic protein signaling enhances invasion and bone metastasis of breast cancer cells through Smad pathway. Oncogene 27 6322-6333.

Kawabata M, Imamura T \& Miyazono K 1998 Signal transduction by bone morphogenetic proteins. Cytokine and Growth Factor Reviews 9 49-61.

Kelleher FC, Fennelly D \& Rafferty M 2006 Common critical pathways in embryogenesis and cancer. Acta Oncologica 45 375-388.

Keller ET, Zhang J, Cooper CR, Smith PC, McCauley LK, Pienta KJ \& Taichman RS 2001 Prostate carcinoma skeletal metastases: cross-talk between tumor and bone. Cancer Metastasis Reviews 20 333-349.

Keski-Oja J, Koli K \& von Melchner H 2004 TGF- $\beta$ activation by traction? Trends in Cell Biology 14 657-659.

Ketolainen JM, Alarmo EL, Tuominen VJ \& Kallioniemi A 2010 Parallel inhibition of cell growth and induction of cell migration and invasion in breast cancer cells by bone morphogenetic protein 4. Breast Cancer Research and Treatment [in press].

Kim IY \& Kim SJ 2006 Role of bone morphogenetic proteins in transitional cell carcinoma cells. Cancer Letters $\mathbf{2 4 1}$ 118-123.

Kim IY, Lee DH, Ahn HJ, Tokunaga H, Song W, Devereaux LM, Jin D, Sampath TK \& Morton RA 2000 Expression of bone morphogenetic protein receptors type-IA, -IB and -II correlates with tumor grade in human prostate cancer tissues. Cancer Research 60 2840-2844.

Kim IY, Lee DH, Lee DK, Ahn HJ, Kim MM, Kim SJ \& Morton RA 2004 Loss of expression of bone morphogenetic protein receptor type II in human prostate cancer cells. Oncogene 23 7651-7659.

Kimura N, Matsuo R, Shibuya H, Nakashima K \& Taga T 2000 BMP2-induced apoptosis is mediated by activation of the TAK1-p38 kinase pathway that is negatively regulated by Smad6. Journal of Biological Chemistry 275 17647-17652.

Kingsley DM 1994 The TGF- $\beta$ superfamily: new members, new receptors, and new genetic tests of function in different organisms. Genes and Development $\mathbf{8}$ 133-146.
Kirkbride KC, Townsend TA, Bruinsma MW, Barnett JV \& Blobe GC 2008 Bone morphogenetic proteins signal through the transforming growth factor- $\beta$ type III receptor. Journal of Biological Chemistry $\mathbf{2 8 3}$ 7628-7637.

Kleeff J, Maruyama H, Ishiwata T, Sawhney H, Friess H, Buchler MW \& Korc M 1999 Bone morphogenetic protein 2 exerts diverse effects on cell growth in vitro and is expressed in human pancreatic cancer in vivo. Gastroenterology 116 1202-1216.

Korchynskyi O, Dechering KJ, Sijbers AM, Olijve W \& ten Dijke P 2003 Gene array analysis of bone morphogenetic protein type I receptor-induced osteoblast differentiation. Journal of Bone and Mineral Research 18 1177-1185.

Kowanetz M, Valcourt U, Bergstrom R, Heldin CH \& Moustakas A 2004 Id2 and Id3 define the potency of cell proliferation and differentiation responses to transforming growth factor $\beta$ and bone morphogenetic protein. Molecular and Cellular Biology 24 4241-4254.

Kretzschmar M, Doody J \& Massague J 1997 Opposing BMP and EGF signalling pathways converge on the TGF- $\beta$ family mediator Smad1. Nature 389 618-622.

Kusumegi T, Tanaka J, Kawano M, Yonemoto J, Tohyama C \& Sone H 2004 BMP7/ActRIIB regulates estrogendependent apoptosis: new biomarkers for environmental estrogens. Journal of Biochemical and Molecular Toxicology 18 1-11.

Langenfeld EM, Bojnowski J, Perone J \& Langenfeld J 2005 Expression of bone morphogenetic proteins in human lung carcinomas. Annals of Thoracic Surgery 80 1028-1032.

Langenfeld EM, Kong Y \& Langenfeld J 2006 Bone morphogenetic protein 2 stimulation of tumor growth involves the activation of Smad-1/5. Oncogene 25 685-692.

Lee HJ, Liu H, Goodman C, Ji Y, Maehr H, Uskokovic M, Notterman D, Reiss M \& Suh N $2006 a$ Gene expression profiling changes induced by a novel Gemini vitamin D derivative during the progression of breast cancer. Biochemical Pharmacology 72 332-343.

Lee HJ, Wislocki A, Goodman C, Ji Y, Ge R, Maehr H, Uskokovic M, Reiss M \& Suh N $2006 b$ A novel vitamin D derivative activates bone morphogenetic protein signaling in MCF10 breast epithelial cells. Molecular Pharmacology 69 1840-1848.

Leung-Hagesteijn C, Hu MC, Mahendra AS, Hartwig S, Klamut HJ, Rosenblum ND \& Hannigan GE 2005 Integrin-linked kinase mediates bone morphogenetic protein 7-dependent renal epithelial cell morphogenesis. Molecular and Cellular Biology 25 3648-3657.

Liu F, Bloch N, Bhushan KR, De Grand AM, Tanaka E, Solazzo S, Mertyna PM, Goldberg N, Frangioni JV \& Lenkinski RE 2008 Humoral bone morphogenetic protein 2 is sufficient for inducing breast cancer microcalcification. Molecular Imaging 7 175-186. 
Luo J, Sun MH, Kang Q, Peng Y, Jiang W, Luu HH, Luo Q, Park JY, Li Y, Haydon RC et al. 2005 Gene therapy for bone regeneration. Current Gene Therapy 5 167-179.

Luu HH, Song WX, Luo X, Manning D, Luo J, Deng ZL, Sharff KA, Montag AG, Haydon RC \& He TC 2007 Distinct roles of bone morphogenetic proteins in osteogenic differentiation of mesenchymal stem cells. Journal of Orthopaedic Research 25 665-677.

Macias-Silva M, Hoodless PA, Tang SJ, Buchwald M \& Wrana JL 1998 Specific activation of Smad1 signaling pathways by the BMP7 type I receptor, ALK2. Journal of Biological Chemistry 273 25628-25636.

Massague J 2003 Integration of Smad and MAPK pathways: a link and a linker revisited. Genes and Development 17 2993-2997.

Massague J \& Gomis RR 2006 The logic of TGF $\beta$ signaling. FEBS Letters 580 2811-2820.

Massague J, Blain SW \& Lo RS 2000 TGF $\beta$ signaling in growth control, cancer, and heritable disorders. Cell $\mathbf{1 0 3}$ 295-309.

Massague J, Seoane J \& Wotton D 2005 Smad transcription factors. Genes and Development 19 2783-2810.

Masuda H, Fukabori Y, Nakano K, Shimizu N \& Yamanaka H 2004 Expression of bone morphogenetic protein-7 (BMP-7) in human prostate. Prostate 59 101-106.

Miyazono K 2000 Positive and negative regulation of TGF- $\beta$ signaling. Journal of Cell Science 113 1101-1109.

Miyazono K, Maeda S \& Imamura T 2005 BMP receptor signaling: transcriptional targets, regulation of signals, and signaling cross-talk. Cytokine and Growth Factor Reviews 16 251-263.

Montesano R 2007 Bone morphogenetic protein-4 abrogates lumen formation by mammary epithelial cells and promotes invasive growth. Biochemical and Biophysical Research Communications 353 817-822.

Montesano R, Sarkozi R \& Schramek H 2008 Bone morphogenetic protein-4 strongly potentiates growth factor-induced proliferation of mammary epithelial cells. Biochemical and Biophysical Research Communications 374 164-168.

Murakami G, Watabe T, Takaoka K, Miyazono K \& Imamura T 2003 Cooperative inhibition of bone morphogenetic protein signaling by Smurf1 and inhibitory Smads. Molecular Biology of the Cell 14 2809-2817.

Newfeld SJ, Wisotzkey RG \& Kumar S 1999 Molecular evolution of a developmental pathway: phylogenetic analyses of transforming growth factor- $\beta$ family ligands, receptors and Smad signal transducers. Genetics 152 783-795.

Nohe A, Hassel S, Ehrlich M, Neubauer F, Sebald W, Henis YI \& Knaus P 2002 The mode of bone morphogenetic protein (BMP) receptor oligomerization determines different BMP-2 signaling pathways. Journal of Biological Chemistry 277 5330-5338.
Nohe A, Keating E, Knaus P \& Petersen NO 2004 Signal transduction of bone morphogenetic protein receptors. Cellular Signalling 16 291-299.

Ong DB, Colley SM, Norman MR, Kitazawa S \& Tobias JH 2004 Transcriptional regulation of a BMP-6 promoter by estrogen receptor $\alpha$. Journal of Bone and Mineral Research 19 447-454.

Onichtchouk D, Chen YG, Dosch R, Gawantka V, Delius H, Massague J \& Niehrs C 1999 Silencing of TGF- $\beta$ signalling by the pseudoreceptor BAMBI. Nature 401 480-485.

Otani H, Otsuka F, Inagaki K, Takeda M, Miyoshi T, Suzuki J, Mukai T, Ogura T \& Makino H 2007 Antagonistic effects of bone morphogenetic protein- 4 and -7 on renal mesangial cell proliferation induced by aldosterone through MAPK activation. American Journal of Physiology. Renal Physiology 292 F1513-F1525.

Peng Y, Kang Q, Cheng H, Li X, Sun MH, Jiang W, Luu HH, Park JY, Haydon RC \& He TC 2003 Transcriptional characterization of bone morphogenetic proteins (BMPs)-mediated osteogenic signaling. Journal of Cellular Biochemistry 90 1149-1165.

Phippard DJ, Weber-Hall SJ, Sharpe PT, Naylor MS, Jayatalake H, Maas R, Woo I, Roberts-Clark D, Francis-West PH, Liu YH et al. 1996 Regulation of Msx-1, Msx-2, Bmp-2 and Bmp-4 during foetal and postnatal mammary gland development. Development 122 2729-2737.

Piccirillo SG, Reynolds BA, Zanetti N, Lamorte G, Binda E, Broggi G, Brem H, Olivi A, Dimeco F \& Vescovi AL 2006 Bone morphogenetic proteins inhibit the tumorigenic potential of human brain tumour-initiating cells. Nature 444 761-765.

Piscione TD, Phan T \& Rosenblum ND 2001 BMP7 controls collecting tubule cell proliferation and apoptosis via Smad1-dependent and -independent pathways. American Journal of Physiology. Renal Physiology 280 F19-F33.

Pouliot F \& Labrie C 2002 Role of Smad1 and Smad4 proteins in the induction of p21WAF1, Cip1 during bone morphogenetic protein-induced growth arrest in human breast cancer cells. Journal of Endocrinology 172 187-198.

Pouliot F, Blais A \& Labrie C 2003 Overexpression of a dominant negative type II bone morphogenetic protein receptor inhibits the growth of human breast cancer cells. Cancer Research 63 277-281.

Raida M, Clement JH, Ameri K, Han C, Leek RD \& Harris AL 2005a Expression of bone morphogenetic protein 2 in breast cancer cells inhibits hypoxic cell death. International Journal of Oncology 26 1465-1470.

Raida M, Clement JH, Leek RD, Ameri K, Bicknell R, Niederwieser D \& Harris AL $2005 b$ Bone morphogenetic protein 2 (BMP-2) and induction of tumor angiogenesis. Journal of Cancer Research and Clinical Oncology 131 741-750. 
Reddi AH 1997 Bone morphogenetic proteins: an unconventional approach to isolation of first mammalian morphogens. Cytokine and Growth Factor Reviews 8 11-20.

Reddi AH 1998 Role of morphogenetic proteins in skeletal tissue engineering and regeneration. Nature Biotechnology 16 247-252.

Reddi AH 2001 Interplay between bone morphogenetic proteins and cognate binding proteins in bone and cartilage development: noggin, chordin and DAN. Arthritis Research 3 1-5.

Reinholz MM, Iturria SJ, Ingle JN \& Roche PC 2002 Differential gene expression of TGF- $\beta$ family members and osteopontin in breast tumor tissue: analysis by real-time quantitative PCR. Breast Cancer Research and Treatment 74 255-269.

Rosenzweig BL, Imamura T, Okadome T, Cox GN, Yamashita H, ten Dijke P, Heldin CH \& Miyazono K 1995 Cloning and characterization of a human type II receptor for bone morphogenetic proteins. PNAS 92 7632-7636.

Samad TA, Rebbapragada A, Bell E, Zhang Y, Sidis Y, Jeong SJ, Campagna JA, Perusini S, Fabrizio DA, Schneyer AL et al. 2005 DRAGON, a bone morphogenetic protein co-receptor. Journal of Biological Chemistry 280 14122-14129.

Sapkota G, Alarcon C, Spagnoli FM, Brivanlou AH \& Massague J 2007 Balancing BMP signaling through integrated inputs into the Smad1 linker. Molecular Cell 25 441-454.

Scherberich A, Tucker RP, Degen M, Brown-Luedi M, Andres AC \& Chiquet-Ehrismann R 2005 Tenascin-W is found in malignant mammary tumors, promotes $\alpha 8$ integrin-dependent motility and requires p38MAPK activity for BMP-2 and TNF- $\alpha$ induced expression in vitro. Oncogene 24 1525-1532.

Scherner O, Meurer SK, Tihaa L, Gressner AM \& Weiskirchen R 2007 Endoglin differentially modulates antagonistic transforming growth factor- $\beta 1$ and BMP-7 signaling. Journal of Biological Chemistry 282 13934-13943.

Schmierer B \& Hill CS 2007 TGF $\beta$-SMAD signal transduction: molecular specificity and functional flexibility. Nature Reviews. Molecular Cell Biology 8 970-982.

Schwalbe M, Sanger J, Eggers R, Naumann A, Schmidt A, Hoffken K \& Clement JH 2003 Differential expression and regulation of bone morphogenetic protein 7 in breast cancer. International Journal of Oncology 23 89-95.

Schwaninger R, Rentsch CA, Wetterwald A, van der Horst G, van Bezooijen RL, van der Pluijm G, Lowik CW, Ackermann K, Pyerin W, Hamdy FC et al. 2007 Lack of noggin expression by cancer cells is a determinant of the osteoblast response in bone metastases. American Journal of Pathology 170 160-175.
Sebald W, Nickel J, Zhang JL \& Mueller TD 2004 Molecular recognition in bone morphogenetic protein (BMP)/ receptor interaction. Biological Chemistry 385 697-710.

Shi Y \& Massague J 2003 Mechanisms of TGF- $\beta$ signaling from cell membrane to the nucleus. Cell 113 685-700.

Shibuya H, Iwata H, Masuyama N, Gotoh Y, Yamaguchi K, Irie K, Matsumoto K, Nishida E \& Ueno N 1998 Role of TAK1 and TAB1 in BMP signaling in early Xenopus development. EMBO Journal 17 1019-1028.

Shon SK, Kim A, Kim JY, Kim KI, Yang Y \& Lim JS 2009 Bone morphogenetic protein-4 induced by NDRG2 expression inhibits MMP-9 activity in breast cancer cells. Biochemical and Biophysical Research Communications 385 198-203.

Siegel PM \& Massague J 2003 Cytostatic and apoptotic actions of TGF- $\beta$ in homeostasis and cancer. Nature Reviews. Cancer 3 807-821.

Sneddon JB, Zhen HH, Montgomery K, van de Rijn M, Tward AD, West R, Gladstone H, Chang HY, Morganroth GS, Oro AE et al. 2006 Bone morphogenetic protein antagonist gremlin 1 is widely expressed by cancer-associated stromal cells and can promote tumor cell proliferation. PNAS 103 14842-14847.

Sopory S, Nelsen SM, Degnin C, Wong C \& Christian JL 2006 Regulation of bone morphogenetic protein-4 activity by sequence elements within the prodomain. Journal of Biological Chemistry 281 34021-34031.

Steinert S, Kroll TC, Taubert I, Pusch L, Hortschansky P, Hoffken K, Wolfl S \& Clement JH 2008 Differential expression of cancer-related genes by single and permanent exposure to bone morphogenetic protein 2 . Journal of Cancer Research and Clinical Oncology 134 1237-1245.

Takahashi M, Otsuka F, Miyoshi T, Otani H, Goto J, Yamashita M, Ogura T, Makino H \& Doihara H 2008 Bone morphogenetic protein 6 (BMP6) and BMP7 inhibit estrogen-induced proliferation of breast cancer cells by suppressing p38 mitogen-activated protein kinase activation. Journal of Endocrinology 199 445-455.

Theriault BL, Shepherd TG, Mujoomdar ML \& Nachtigal MW 2007 BMP4 induces EMT and Rho GTPase activation in human ovarian cancer cells. Carcinogenesis 28 1153-1162.

Tsuchida K, Sunada Y, Noji S, Murakami T, Uezumi A \& Nakatani M 2006 Inhibitors of the TGF- $\beta$ superfamily and their clinical applications. Mini Reviews in Medicinal Chemistry 6 1255-1261.

Valcourt U, Kowanetz M, Niimi H, Heldin CH \& Moustakas A 2005 TGF- $\beta$ and the Smad signaling pathway support transcriptomic reprogramming during epithelial-mesenchymal cell transition. Molecular Biology of the Cell 16 1987-2002. 
Vessella RL \& Corey E 2006 Targeting factors involved in bone remodeling as treatment strategies in prostate cancer bone metastasis. Clinical Cancer Research 12 $6285 \mathrm{~s}-6290 \mathrm{~s}$.

Waite KA \& Eng C $2003 a$ From developmental disorder to heritable cancer: it's all in the BMP/TGF- $\beta$ family. Nature Reviews. Genetics 4 763-773.

Waite KA \& Eng C 2003b BMP2 exposure results in decreased PTEN protein degradation and increased PTEN levels. Human Molecular Genetics 12 679-684.

Wakefield LM, Piek E \& Bottinger EP 2001 TGF- $\beta$ signaling in mammary gland development and tumorigenesis. Journal of Mammary Gland Biology and Neoplasia 6 67-82.

Wang N, Lin KK, Lu Z, Lam KS, Newton R, Xu X, Yu Z, Gill GN \& Andersen B 2007 The LIM-only factor LMO4 regulates expression of the BMP7 gene through an HDAC2-dependent mechanism, and controls cell proliferation and apoptosis of mammary epithelial cells. Oncogene 26 6431-6441.

Welsh J 2007 Vitamin D and prevention of breast cancer. Acta Pharmacologica Sinica 28 1373-1382.

Wilkinson L, Kolle G, Wen D, Piper M, Scott J \& Little M 2003 CRIM1 regulates the rate of processing and delivery of bone morphogenetic proteins to the cell surface. Journal of Biological Chemistry 278 34181-34188.

Wozney JM 2002 Overview of bone morphogenetic proteins. Spine 27 S2-S8.

Wozney JM \& Rosen V 1998 Bone morphogenetic protein and bone morphogenetic protein gene family in bone formation and repair. Clinical Orthopaedics and Related Research 346 26-37.

Wozney JM, Rosen V, Celeste AJ, Mitsock LM, Whitters MJ, Kriz RW, Hewick RM \& Wang EA 1988 Novel regulators of bone formation: molecular clones and activities. Science 242 1528-1534.

Yamaguchi K, Nagai S, Ninomiya-Tsuji J, Nishita M, Tamai K, Irie K, Ueno N, Nishida E, Shibuya H \& Matsumoto K 1999 XIAP, a cellular member of the inhibitor of apoptosis protein family, links the receptors to TAB1-TAK1 in the BMP signaling pathway. EMBO Journal 18 179-187.

Yamamoto T, Saatcioglu F \& Matsuda T 2002 Cross-talk between bone morphogenic proteins and estrogen receptor signaling. Endocrinology 143 2635-2642.

Yan W \& Chen X 2007 Targeted repression of bone morphogenetic protein 7, a novel target of the p53 family, triggers proliferative defect in p53-deficient breast cancer cells. Cancer Research 67 9117-9124.
Yang S, Zhong C, Frenkel B, Reddi AH \& Roy-Burman P 2005 Diverse biological effect and Smad signaling of bone morphogenetic protein 7 in prostate tumor cells. Cancer Research 65 5769-5777.

Yang S, Du J, Wang Z, Yuan W, Qiao Y, Zhang M, Zhang J, Gao S, Yin J, Sun B et al. 2007a BMP-6 promotes E-cadherin expression through repressing deltaEF1 in breast cancer cells. BMC Cancer 7211.

Yang X, Lee PJ, Long L, Trembath RC \& Morrell NW 2007b BMP4 induces HO-1 via a Smad independent, p38MAPK dependent pathway in pulmonary artery myocytes. American Journal of Respiratory, Cell and Molecular Biology 37 598-605.

Yang S, Du J, Wang Z, Yan J, Yuan W, Zhang J \& Zhu T 2009 Dual mechanism of deltaEF1 expression regulated by bone morphogenetic protein- 6 in breast cancer. International Journal of Biochemistry \& Cell Biology 41 853-861.

Ye L, Lewis-Russell JM, Kyanaston HG \& Jiang WG 2007 Bone morphogenetic proteins and their receptor signaling in prostate cancer. Histology and Histopathology 22 1129-1147.

Yoshikawa H, Nakase T, Myoui A \& Ueda T 2004 Bone morphogenetic proteins in bone tumors. Journal of Orthopaedic Science 9 334-340.

Zeisberg M, Hanai J, Sugimoto H, Mammoto T, Charytan D, Strutz F \& Kalluri R 2003 BMP-7 counteracts TGF- $\beta 1$-induced epithelial-to-mesenchymal transition and reverses chronic renal injury. Nature Medicine 9 964-968.

Zhang M, Yan JD, Zhang L, Wang Q, Lu SJ, Zhang J \& Zhu TH 2005 Activation of bone morphogenetic protein-6 gene transcription in MCF-7 cells by estrogen. Chinese Medical Journal 118 1629-1636.

Zhang M, Wang Q, Yuan W, Yang S, Wang X, Yan JD, Du J, Yin J, Gao SY, Sun BC et al. 2007 Epigenetic regulation of bone morphogenetic protein-6 gene expression in breast cancer cells. Journal of Steroid Biochemistry and Molecular Biology 105 91-97.

Zhao GQ 2003 Consequences of knocking out BMP signaling in the mouse. Genesis 35 43-56.

Zhu W, Kim J, Cheng C, Rawlins BA, Boachie-Adjei O, Crystal RG \& Hidaka C 2006 Noggin regulation of bone morphogenetic protein (BMP) 2/7 heterodimer activity in vitro. Bone 39 61-71.

Zwijsen A, Verschueren K \& Huylebroeck D 2003 New intracellular components of bone morphogenetic protein/Smad signaling cascades. FEBS Letters 546 133-139. 